\title{
Tips for Principal in Managing One Roof Scool (SATAP) in Underdeveloped Area
}

\author{
Bagus Rachmad Saputra \\ Department of Educational Management \\ Universitas Negeri Malang, Indonesia \\ bagusrachmad47@gmail.com \\ Maulana Amirul Adha \\ Department of Educational Management \\ Universitas Negeri Malang, Indonesia \\ amirulmaulana1013@gmail.com
}

\author{
Nova Syafira Ariyanti \\ Department of Educational Management \\ Universitas Negeri Malang, Indonesia \\ novasyafira2@gmail.com \\ Imam Gunawan \\ Department of Educational Administration \\ Universitas Negeri Malang, Indonesia \\ imam.gunawan.fip@um.ac.id
}

\begin{abstract}
This study aims to describe: (1) the principal's tips on managing Satap schools in distantly areas; and (2) the results achieved by Satap schools in efforts to improve the quality of single schools in distantly areas carried out by principals. This study uses a qualitative research approach with a multi-site study approach conducted at Satap schools in Polewali Mandar and Mamuju Regencies, West Sulawesi and Bondowoso District, East Java. Data were obtained through interviews with school principals, teachers, and representatives of surrounding communities to obtain in-depth information about the Satap school understudy. Data were collected from two sites in the form of structured and unstructured interviews, participatory observation, and documentation studies. The results of this study are: (1) the form of tips for principals in managing Satap schools in distantly areas; and (2) the results achieved by Satap schools in efforts to improve the quality of single schools in distantly areas carried out by principals.
\end{abstract}

Keywords: tips principal, one roof school, underdeveloped area

\section{INTRODUCTION}

The principal's role is imperative for the management of a school. There is no exception for a oneroom school, a school that is born to address the access gap of education in lagging regions and suburbs. The role of the headmaster is so important for the one roof school because of the many problems that arise in school management because of the limitations of supporting facilities and infrastructure in the disadvantaged areas. Areas where infrastructure access is sometimes still not maximally touched by development in the area [1], [2] Never before the problem of school spacing with the community environment and culture of the local people who sometimes make the support of the community to the one roof school is considered less. Moreover, the challenges faced will be more complex when leading and managing two educational institutions in different levels integrated into one roof school [3]. Of course, these problems required tips from the principal to solve the problem. School principals are expected to play the role of leaders and managers well [4]. Involving community participation in the management of "sekolah satu atap" primarily approaches to cultural aspects.

It is undeniable that the culture of a society can influences the management of the school. For example, a one roof school in a plantation area is faced with the question of many learners who do not go to school because they help their parents in the garden. It needs a wide range of approach strategies to be done by the headmaster so that students can join the learning program accordingly. A personal approach with students parents or with a garden foreman is important to suppress learners from skip to school [5], [6].

Such tips are required by the headmaster in managing a one-stop school in a distant area. Including how to make use of the conditions around the school are limited to the average learning resources. Involvement of local community leaders in supporting school efforts to improve school quality is also the principal's concern [7], [8]. How the headmaster can make a persuasive approach with community leaders around the school so that the programs compiled by the one roof school are acceptable and supported by the local community [9]. Therefore, this research seeks to photograph the problem by researching Polewali Mandar and Mamuju West Sulawesi and Bondowoso East Java where there are several one roof schools in the area.

\section{METHODS}

The study used a qualitative approach with the design of a multi-site study. Multi-site studies are draft research by involving several sites and research subjects as a case. Where research subjects are assumed to have different characteristics [10]. This research data consists of the results of data collection through interview activities, participatory observation results, and document studies. Presented in field notes, transcript interviews, and documentation.

Data analysis is done by a constant comparative method whereby data collection is done repeatedly and then analyzed after data collection is finished through the data source triangulation techniques and techniques to ensure the validity of data in Both sites [11]. The data analysis stage is done by checking the credibility of the data obtained by checking the data obtained from sources with different techniques to test the validity of the data obtained. The data obtained is also tested for validity and legitimacy on some sources to get the data that is truly accurate, trustworthy, and following the facts of the field.

\section{RESULTS}

From the research findings conducted by researchers during the field. Research findings are as follows: (1) the school principal tips for managing the Satap school in 
distantly areas; and (2) the results achieved by SATAP schools in the efforts to improve the quality of the SATAP schools in distantly areas conducted by the head School. There is a difference in the headmaster's tips for managing Satap in distantly areas between the Satap headmaster at Polewali Mandar and Mamuju with the principal of Satap at Bondowoso. The strategy approach performed by the school principal of Satap in Polewali Mandar and Mamuju further leads to the socio-cultural approach of local wisdom surrounding the community around Satap.

The approach to cultural aspects of local communities and the involvement of indigenous elders is key to the headmaster to implement the school program by involving the role of the customary elders. An example of a cultural approach to local wisdom is the approach of people's perspective in seeing issues such as Mua Mettamai Tau Lambegna Di Kampugna Tau Hai Penna Lambegnathat means coming to the village of people behold the indifferent tree. Where the simple meaning is if the school program wants to be carried out well then the principal should involve the participation of local customary elders as the most followed figures by the community.

Meanwhile, the school principal tips in managing the Satap school in Bondowoso culturally is reviewed from the economic life aspects of the majority of the community as plantation labourers. The headmaster collaborated with local communities as well as plantations in the vicinity of the school, and the headmaster conducted a participatory approach in which every school program always involved the participation of communities around the school.

Community participation in such a community around a school that has land can be used by schools to be planted with fruits or vegetables, when the land owned by the residents used by the school is experiencing Harvest season, the school also shares the results with the residents, and from the harvest can be sold to help pay the salary of the teacher or can be included in the school cash in order to cover the funds from the government Hasn't descended.

The headmaster's effort to raise the quality of the school in a way to make maximum efforts despite all limitations in terms of lack of teachers, limitations of facilities and infrastructure, and budget constraints as well, what about These limitations of the school can still run all school activities well and smoothly without any obstacles. The headmaster collaborated with Sinder or plantation foreman if students were involved in the activities of his parents in the garden, then the threat was not hired anymore in the plantation. Learners must enter school and can only help gardening when it is time for school or holiday. This strategy was conducted by the headmaster to reduce the school's number of schools by learners on the grounds of assisting their parents in the plantation.

Meanwhile, for the constraints experienced by the school principal Satap in Polewali Mandar, Mamuju, and Bondowoso relatively the same. The problem is the limitation in human resources, school facilities and infrastructure limited, as well as the financial matters that sometimes the headmaster disbursers personal funds to make an up temporary budget for funds Schools especially for the salary payment of teachers who are on average not permanent teachers (GTT). The barriers to human resources in the areas of Polewalimandar, Mamuju, and Bondowoso are relatively equal to the limitations of teachers who are ready to be placed in distant areas. Average teachers are reluctant to teach in distantly areas of SATAP because the terrain that is passed to reach to the school is too far and access roads are less supportive because some have not yet been paved. The demands of devotion that should be a daily basis in distantly areas resulted in the majority of teachers not being prepared and not willing to be placed on the SATAP. If you want the most with a relatively small amount and the unwilling to submit resignation especially GTT teachers because to support the cost of living felt less.

While the other obstacles are still in the context of the HR barriers that are from their people who lack understanding the meaning of education. Besides, the economic level of society that is relatively low causes children to work to help the family economy. The mindset of most local people considers that children who get educated in elementary school and who are educated in junior high school are no different in assisting the work of parents in the sea and the fields, causing parents to be reluctant into a higher level of education. The attention that parents give to students about the importance of education is still minimal, it will certainly impact students ' interest in school.

In addition, the facilities and infrastructure are the limitation of classrooms, because there are students in grade 6 "Satap" from "Mamuju Panteran" who still use junior high school classrooms, do not have a school library when the importance of the school library as a place to study or Educational professionals find a source of reference or learning materials. Bathroom facilities are limited because the school only has two bathrooms, but the number of students is 124 students. Limited sports facilities, limited sports facilities in the area of Mamuju is there is no volleyball and basketball, and also every student sports badminton learning is needed to bring their equipment, so in the area of Mamuju there Only a large land with high school. While Satap in Polewalimandar area is not so lacking sports facilities the only schoolyard is less spacious.

The limitations in financial matters are relatively similar between Mamuju, Polewalimandar, and Bondowoso because the average parent of learners only works as fishermen and plantation workers. When the parents are withdrawn tuition that is immediately the Guardian can only pay only one thing in being able to cover the budget needs of the school. While the budget of the Bantuan Operasional Sekolah (BOS) is only used to pay honorary teachers of approximately Rp 150,000 per month when the boss funds fall every three months and adjusted to the number of students. While the number of learners in SATAP is not too much. Therefore, the school principal must be willing to spend their money in advance to pay the honorary teacher by implementing the management of the school-based Godhead and Keikhlasan as a manifestation of their devotion in managing The Satap. 


\section{DISCUSSION}

A. Form of Principal Tips in Managing the Satap School in Distantly Areas

The problem in Satap besides being in a lagged area far away from the city centre. Another problem is the limitation of the implementation of school activities. Limited funds budget, educated teachers are not linear with the subjects taught, the support of low society to school activities is a problem for the school head Satap in the disadvantaged area. The problem requires the school principal to be able to portray the role well, as a leader or manager in the school [3], [7], [9]. Seeing the problem in the management of SATAP, can not be removed from the management support factor of the SATAP itself. Cultural, economic, geographical, and historical factors are the factors that the head of Satap has to do in drafting school management strategies.

The cultural factor were humans in a group of living together and called the community is an element that cannot be released in the approach to society [8], [12] Culture is a public identity and in it, there are dogma and values are so inherent, of course, the principal must formulate a strategic approach to the community around the school appropriately [7]. Principals need to know even the need to engage in community activities to create a close relationship between the school and the community [5], [6], [13]. Both the Satap visited by researchers at Polewali Mandar, Mamuju, and Bondowoso almost have the same thing that if you want to involve the role of society, then schools need to approach influential people in the society. form of the school's strategy in involving local community participation is to invite the cooperation of indigenous elders and plantation foreman who have a strong influence on the community to support school policies.

Like the case at Satap Sempol Bondowoso where learners rarely enter into teaching and learning activities at school. The headmaster was encouraged by inviting garden Foreman to cooperate if the plantation labourers took their children to the garden and not the school, so they would be dismissed as plantation laborers. The results were effective, many learners attended school and just helped their parents on the plantation after returning to school. This is one of the tips that is required by the headmaster in addressing a problem because problems about cultural aspects are a complicated problem and need to use a persuasive approach with the main characters in Community [2], [4], [14].

$\mathrm{Be}$ in a disadvantaged area and rely on sea and gardening as a livelihood. The condition of the community is classified as middle-downward. The issue of the school's operational assistance through BOS funds is limited to the amount demanding that the head of Satap in the disadvantaged area to be creative looking for alternative problem-solving solutions. Not to mention coupled with the salary burden of an honorary teacher to be paid are the problems that must be resolved by the principal Satap in the disadvantaged area. School activity cannot be removed from the availability of budget sources that support school activities. Some alternative strategies need to be done by the headmaster in resolving these budget constraints [2], [15]. Strategy in cooperation with the plantation and the school Kewirausaahan program can be an alternative solution to explore the source of school funds. As in Satap Sempol and Krujukan Bondowoso which makes entrepreneurship program to utilize natural resources that exist around the school such as processing school fields, making orange juice, making ginger instant, and making noodles without Only as a learning activity but also a source of insertion for schools. Similarly, the Satap in Polewali Mandar and Mamuju also implemented a strategy that is almost the same. This creativity is needed by the headmaster to overcome the limitations of economic factors so that school activities can run well [7], [16].

Located in a distant area or disadvantaged with insufficient infrastructure support is certainly a problem for the school principal Satap. But behind all these limitations, the headmaster has the responsibility to perform the learning activities in the best possible. Therefore, principals need to see the potential of nature around the school that can be developed not only as a learning resource but also the support of school activities. Seeing the potential of a school principal should be able to find the right strategy to manage that potential. Entrepreneurship program becomes an alternative to addressing the problem [1], [17]. Next is the historical side or history of the school itself needs to be in the attention of the headmaster. Principals need to learn from past events so that every policy taken by the school has no resistance from the surrounding community.

\section{B. The Results Achieved by the SATAP School in the Quality Improvement Efforts of The SATAP Schools in Distantly Areas Conducted by the School Principal}

The principal tips in Satap disadvantaged when done with the right strategy can bring good results to the principal. Through a variety of approaches and ideas done by the school principal problems in the lagging areas can be solved [7], [18], [19]. The result is in the middle of the limitation, Satap in the lagging area can still compete with public schools located in the city centre. Academic and non academic achievement is proof of the success of school principals in managing schools in lagging areas. Satap in Polewali Mandar and Mamuju several times achieving academic and non-academic achievement by participants in the middle of school limitations. Students are successful in achieving achievements both at the district level and in the district, level competing with public schools.

While in Bondowoso, Satap in the area has successfully developed school entrepreneurship by utilizing schoolyards into fruit and vegetable farms that can be sold for school operations. Then cultivate the crops into a product that is worth more. Utilizing red ginger plants that are found in the area Sempol Bondowoso, red Ginger converted into instant ginger juice developed by learners, teachers, principals, and local people who shoulder shoulders in the business. Besides, there is also orange juice and chewy noodles without preservatives that utilize the natural resources around the school. The key lies in how the school principal looks at a problem in the lagging area by implementing the right tips to find the solution to the problem solving [20], [21]. As a Peraturan Menteri Pendidikan Nasional (Permendiknas) No 13 Tahun 2007 about standard Kompetensi Kepala Sekolah 
that the headmaster should have managerial competence, personality, supervision, social, and entrepreneurship. If the competency is understood and practised in the form of school management strategy. Like any condition faced by the school, school activities can still run well.

\section{Conclusion}

From the results of the above discussion, the conclusion of the study is: (1) The school principal's tips for managing a SATAP school in a remote area is realized in the head of the school in cooperation with the local and also existing plantations around the school, head Schools always involve the participation of communities around the school and emerging terms of divine management, sincerity, and local wisdom as a form of the principal's tips in managing Satap in distantly areas. (2) The results achieved by the SATAP school in the efforts to improve the quality of the school in remote areas conducted by the Headmaster, realized in all schools activities can run well despite the limitation of educators, Infrastructure, and financial limitations. Where the achievements achieved by learners at any level become a proud achievement for SATAP in distant areas.

From the above conclusion, the research suggests is addressed to: (1) the school principal needs to manage schools with creative ideas amid the limitations of SATAP in remote areas and initiatives to alternative utilizing learning resources and roles And the community in overcoming the limitations faced by SATAP in distantly areas; and (2) teachers in SATAP need to have a strong commitment in carrying out community devotion in remote areas through learning in existing SATAP and utilizing the surrounding environment as a learning resource and creative in developing potential Around Satap into a product of economic value; and (3) parents are expected to encourage their children to go to school and to pursue the pursuit of higher ideals and education and to be directly involved in the management of Satap through a pledge of advice Given to the principal of Satap.

\section{REFERENCES}

[1] A. Gibson, "Principals' and teachers' views of spirituality in principal leadership in three primary schools," Educ. Manag. Adm. Leadersh., vol. 42, no. 4, pp. 520-535, 2014.

[2] D. Hopkins, Improving the Quality of Education for All : A Handbook of Staff Development Activities. 2015.

[3] D. S. Istiningsih, "Studi Deskriptif Upaya Guru Pkn Dalam Menanamkan Sikap Nasionalisme Pada Siswa Smp Negeri Satu Atap Merjosari Kota Malang (other," Univ. Muhammadiyah Malang., 2013.

[4] Ayene Tamrat Atsebeha, Principals' Leadership Styles and Their Effects on Teachers' Performance in the Tigray Region of Ethiopia. University of South Africa, 2016.

[5] W. Wijayanti, Implementasi Kebijakan SDSMP Satu Atap (Studi Multisitus di Kecamatan Ngablak, Pakis dan
Sawangan Kabupaten Magelang. Program Pascasarjana UM, 2011.

[6] N. D. Wulandari2, "Pengaruh Penggunaan Gadget Terhadap Tingkat Prestasi Sisswa SMP N Satu Atap Pakis Jawa Karawang," J. Ilmu Pengetah. Dan Teknol. Komput., 2018.

[7] Juharyanto, "Kepemimpinan unggul Kepala Sekolah Dasar Daerah Terpencil (Studi Multisitus pada Sekolah Dasar di Kabupaten Bondowoso)," J. Sekol. Dasar, vol. 1, no. Tahun 26, pp. 89-100, 2017.

[8] G. Tchibozo, "Cultural and Social Diversity and the Transition from Education to Work.," Guy Tchibozo, Ed, vol. 17,2013

[9] A. Juharyanto, Arifin, I, Sultoni, \& Nurabadi, "Kepemimpinan Kepala Sekolah Dalam Penguatan Peran Multi Stakeholder Forum: Masalah dan Strategi Solutif Peningkatan Mutu SD-SMP Satu Atap di Daerah Terpencil," J. Sekol. Dasar, vol. 1, no. 28, pp. 1-10, 2019.

[10] N. Ulfatin, Metode Penelitian Kualitatif di Bidang Pendidikan: Teori dan Aplikasinya. Malang: Media Nusa Creative, 2015.

[11] S. . Bogdan, R.C \& Biklen, Qualitative Research for Education An Introduction to Theory and Methods. boston: Allyn and Bacon, Inc., 1982.

[12] L. J. Faegerlind, I., \& Saha, Education and National Development: A Comparative Perspective. Elsevier, 2016.

[13] S. . Sari, "Manajemen peserta didik pada sekolah satu atap sebagai penuntasan wajib belajar di daerah terpencil," Manaj. Pendidik., vol. 23, pp. 563-571, 2012.

[14] T. Trianton, "Dalam Khazanah Budaya Cablaka. Ibda'," $J$. Kebud. Islam, vol. 11, no. 2, pp. 211-226, 2015.

[15] C. Chung and M. Mason, "Why Do Primary School Students Drop Out in Poor, Rural China? A portrait sketched in a distantly mountain village," Int. J. Educ. Dev., vol. 32, no. 4, p. 537545, 2012.

[16] M. Hefni, "Buppa'-Bhabhu-Ghuru Rato (Studi Konstruktivisme-Strukturalis tentang Hierarkhi Kepatuhan dalam Budaya Masyarakat Madura," Karsa, vol. 11, no. 1, 2007.

[17] A. I Made Artha Wibawa, Eka Afnan Troena, Armanu, NoermijatiLumpkin, "The Role of Organizational Culture on Spiritual Leadership, Human Capital, and Employee Loyalty," Eur. J. Bus. Manag., vol. 6, no. 21, pp. 196-205, 2014.

[18] V. B. Tveit, A. D., Cameron, D. L., \& Kovač, “Two Schools under one Roof' in Bosnia and Herzegovina: Exploring the challenges of group identity and deliberative values among Bosniak and Croat students," Int. J. Educ. Res., vol. 66, pp. 103-112, 2014.

[19] A. Urick, "Examining US principal perception of multiple leadership styles used to practice shared instructional leadership," J. Educ. Adm., vol. 54, pp. 152-172, 2016.

[20] H. Yuliastuti, I., Syukri, M., \& Martono, "Principals' leadership in implementing one roof school in Kuala Mandor District [Kepemimpinan kepala sekolah dalam menyelenggarakn pendidikan sekolah satu atap di Kecamatan Kuala Mandor]," J. Pendidik. Dan Pembelajaran., 2016.

[21] B. Zakub, R., Widodo, S. T., \& Setiawan, "The Relevance Between Javanese Pitutur Luhur and Islam Religiosity," $J$. Kaji. Islam dan Budaya, vol. 16, no. 1, pp. 148-164, 2018. 